\title{
O TEATRO DA CIA. A RÃ QI RI ATADO AOS "NÓS" DA PALAVRA
}

\author{
Ligia Karina Martins de Andrade* \\ Universidade Federal de Integração Latino-Americana
}

"Nós Atados" (2012) é a primeira peça teatral publicada por Nereide Santiago na cidade de Manaus. Entretanto, a atuação da diretora e sua Companhia A Rã Qi Ri já é reconhecida no cenário regional de longa data, apesar de menos conhecida no cenário nacional, contando com algumas apresentações em festivais e mostras (BANDEIRA, 2011).

A cuidadosa edição da Editora Valer, sob os cuidados de Tenório Telles, e da qual participam os próprios atores do grupo, tal como o designer gráfico Rodrigo Verçosa dão um toque de inovação e estilo próprio do teatro da Companhia e sua impar atuação na capital da Amazônia. As cores e o designer inovador dão um tom de elegância e precisão, além de apresentar as fotografias tomadas dos bastidores do Grupo ou de momentos da performance do mesmo no palco, preparando o leitor para a leitura que empreenderá.

A peça aborda questões universais, e foge de um possível clichê regional que, não raro, trata os temas locais sob o signo da domesticação ao olhar estrangeiro ou visitante. É por meio de uma prosa filosófica e literária que o texto coloca em cheque a possibilidade do entendimento e da comunicabilidade entre os homens e os problemas daí decorrentes. As personagens parecem perseguir uma busca incansável por meio da revisão de suas vidas. É ao longo de suas trajetórias, ora na ousadia, vacilação, franqueza, ora no jogo, ironia, riso que elas mostram as várias facetas de sua identidade contraditória.

Tanto as posições das personagens quanto os diálogos travados alternam-se como num tabuleiro de xadrez, onde a cada lance corresponde um prisma do jogo ou manobra do jogador, mas o que parece estar de fato em disputa é a ênfase na real ou ilusória existência (significativa!) das personagens (Ulysses, Jonas, Sabina e Lia, além das demais) ora para si

EY No NO Esta obra está licenciada sob uma Licença Creative Commons.

\footnotetext{
* Professora de língua espanhola na UNILA (2013-atual). Atuou também na Universidade Federal do Amazonas (2004-2013). Possui doutorado (2009) e mestrado (2004) pela Universidade de São Paulo.
} 
mesmas ora para o outro. Isto associa cada lance do jogo ou ocasião de revelar(-se) pela fala, acompanhada ou não de mudança do espaço físico da cena, o qual desenha movimentos minimalistas no palco por parte das personagens que ocupam espécies de caixas-casas, objetos ressignificados no teatro e que cobrem novas redes de sentidos a serem percorridos, segundo Ubersfeld (1989) e Santiago (2008). Estas caixas-casas parecem privilegiar o isolamento e o monólogo interior, mas na verdade as personagens primam pelo constante esforço em busca do diálogo e do outro, seja a outra personagem seja o Outro interiorizado no eu, no sentido de que cada personagem aloja dentro de si este Outro de si mesmo como um hóspede desejado, mas por vezes conflitante.

A palavra desejada, aquela que significa da maneira adequada e sem desvios, em vez de encontrar lugar no discurso das personagens, é ironizada e desmistificada a todo instante. O leitor/espectador, constantemente solicitado, se se deixar levar pelo jogo articulado sairá com a plena sensação de participar da ficção e, juntamente com as personagens, experimentar a sensação de estar amarrado pela mesma condição, isto é, a de estar fadados a significar, ainda que sob o risco da incompreensão.

Em vez de desembaralhar os fios trançados, o desenrolar da peça coloca mais indagações e dúvidas. É nessa urdidura complexa e instigante que as personagens dialogam com seu desejo, angústia e expectativas, falam das palavras mesmas (seu peso, força, violência, fragilidade, silêncio...) e sempre percorrem a busca do entendimento de si e do outro, ainda quando o fio do discurso se esgarce cada vez mais aos olhos do público.

O espaço cenográfico favorece o isolamento por meio das caixas-casas e da disposição das personagens em alta/baixa, direita/esquerda, bem vestida/andrajosa, etc., criando uma série de posicionamentos discursivos e - por que não - sociais e culturais. Entretanto, a autora explora, para além de um maniqueísmo sócio-econômico facilmente administrável, os recônditos da alma humana e suas alegrias ou mazelas, egoísmo ou generosidade, revelando no discurso o momento de possível abertura ao outro ou o sufocar no próprio eu, segundo um complexo movimento da cena do interior das personagens ao exterior, passagem e, novo enquadramento. Os limites comportados pelo espaço e pelos praticáveis, limite ainda do próprio corpo, não podem aprisionar ou conter as vidas que ali se esboçam com seus sonhos, ilusões e dialéticas...

A indagação crucial coloca-se ao espectador, que é desalojado de um falso conforto inicial e lançado ao desafio da palavra que se revela logo de cara representação. Diante disso, este espectador é convidado a entrar em cena, é convocado à reflexão, para, em seguida, 
sofrer junto com as personagens a sensação de fragmentação e deslocamento -termo tomado de Said Ali. Este deslocamento afeta desde a representação artística até a própria linguagem e ambas entram em crise. A solução colocada pela autora é a poesia, poesia que inunda cada gesto, movimento e dizer (poesia tão cara à concepção do teatro de Lorca e que a personagem Jonas recorda com seu perpetuo auto-flagelo). Esta via poética entra na malha dialógica do texto, enredando-se numa ampla tradição literária desde Ulysses de James Joyce até o teatro de Ionesco, Beckett..., numa construção intertextual rica e polifônica, marcada ainda pela presença da literatura brasileira (Drummond...), da musicalidade, etc.

Ao término do espetáculo, a sensação é de identificação por parte do público com as personagens, ao lado de um questionamento se o lugar ocupado em cena -ali ou aquicorrespondia ou não, se a palavra era ilusória, se o que ocorre em cena é ilusão e artifício, se houve assassinato ou não, se a matéria das coisas e a de que estamos feitos é essa mesma ou não, entre outras possíveis perguntas. Somos arremessados, portanto, à autorreflexão e saímos com a sensação de que compomos o tecido que, na medida em que era trançado, também nos "atou" por meio dos "nós" da palavra.

\section{Referências}

BANDEIRA, Jorge. A busca do teatro de Nereide Santiago. O Caminho de Santiago. Revista Ensaio Geral, Belém, UFPA, v.3, n.5, p. 1-4, 2011.

SANTIAGO, Nereide. Do texto à cena: funções do objeto. In: CONGRESSO INTERNACIONAL DA ABRALIC, 11., 2008, São Paulo. Anais... São Paulo: USP, 2008. p. 02-04.

Nós Atados. Manaus: Editora Valer, 2012.

UBERSFELD, Anne. Semiótica Teatral. Madrid: Ediciones Cátedra, 1989.

[Recebido em dezembro de 2013 e aceito para publicação em junho de 2014]

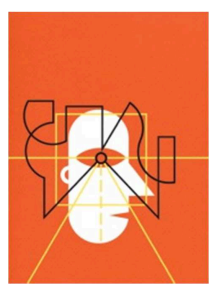

